\title{
1. Introduction to Transit Oriented Development and Sustainable Cities: Economics, Community and Methods
}

\section{Richard D. Knowles and Fiona Ferbrache}

\section{OVERVIEW}

This book on Transit Oriented Development and Sustainable Cities: Economics, Community and Methods provides new dimensions and a contemporary focus on sustainable transport, urban development and regeneration across a wide range of countries and levels of development. It builds on seminal contributions on transit oriented development (TOD) by Calthorpe (1993), Cervero (1998), Dittmar and Ohland (2003) and Curtis et al. (2009), and examines the contemporary role of TOD in improving urban sustainability and providing transport choices. This focus is of critical importance in the light of growing concerns about urban sustainability in the face of a range of economic, social, political and environmental issues including competition for capital, uneven development, gentrification, social justice, urban democracy, congestion, car dependence, transport emissions, global warming, peak oil and the challenge of powering transport with sustainable fuels (Renne and Fields, 2013).

Chapters feature cutting-edge and topical research in eight countries in four continents by eminent researchers based in six countries. They build on a series of papers on 'Transport, Sustainable Cities and Transit Oriented Development' presented at the Royal Geographical Society Conference in London in September 2017. The concluding chapter synthesizes this new range of knowledge on impacts of TOD and its potential to enhance urban sustainability. A new agenda for TOD is created by critically evaluating contemporary links between sustainable transport investment, TOD and urban sustainability, focusing on economic and social development as well as on TOD methods. Furthermore, building on the explicit economic and social sections of the book, the concluding chapter (Chapter 14) draws out some of the relations between and across the empirical chapters towards 
a more 'critical' approach to TOD and its potential to enhance urban sustainability.

\section{INTRODUCTION: LINKS BETWEEN TRANSPORT INVESTMENT, TRANSIT ORIENTED DEVELOPMENT AND SUSTAINABILITY}

This introduction examines the role of TOD in improving urban sustainability and providing transport choices, opening up new dimensions and a contemporary focus on sustainable transport, urban development and urban regeneration. TOD is the process of focusing the development of housing, employment, activity sites and public services and facilities around existing or new rail or bus rapid transit stations or stops. Although the term 'TOD' was defined by Calthorpe only in the late 1980s, and published in 1993, when he specified the three 'Ds' - density of development and activity sites, diversity of land use, and design of dense urban grids with pedestrianized environments - as key characteristics of TOD, the process described can be traced back to the nineteenth century (Knowles, 2017; Knowles et al., 2019 under review). Ewing and Cervero (2010) identified three more 'Ds': distance to transit, destination accessibility, and demand management. Knowles (2016) more recently highlighted the prerequisite for successful TOD of high-frequency peak and off-peak rapid transit services by rail, light rail or bus.

An extensive body of geographic and economic theory links transport with land use, as accessibility affects the value of land. Seminal contributions to location theory include Christaller's work in the 1930s on the distribution of central places (Christaller, 1966), Hoyt's (1939) sector model of urban land use, and Alonso's (1964) urban land rent theory. Alonso linked urban transport infrastructure improvements to increased land and property values through enhanced accessibility. The potential opportunities for interaction are highest in the most accessible locations such as the central business district (CBD) (Hansen, 1959). With mass car ownership and use, and urban road traffic congestion, some economic activity has relocated to more accessible sites on the urban periphery in edge cities or suburban downtowns (Garreau, 1991; Hartshorn, 1992). TOD improves accessibility and enhances activity and land uses around transit stations and stops, and in CBDs. Geurs and van Wee (2004, p. 128) define accessibility as 'the extent to which land use and transport systems enable (groups of) individuals to reach activities or destinations by means of a (combination of) transport mode(s)'. Travel time and cost are both key elements in an individual's choice of modes (Banister, 2011). 
Historically, the concept of TOD is closely associated with both tram and train route development and urban expansion in the late nineteenth century, when transit investment produced a step-change in accessibility, and shaped urban and suburban expansion with captive traffic before private car ownership came to dominate urban forms (Knowles, 2017). In the midtwentieth century, planned TOD started with Copenhagen's 1947 Finger Plan, facilitating suburban development along radial rail corridors and creating captive traffic for rail transit services (Knowles, 2012). Oslo (1950), Stockholm (1952) and Paris (1965) also initiated planned rail-based TOD. In the second half of the twentieth century, widespread private car ownership and availability in most developed countries gave many urban residents modal choice, and public transport use declined. More recently, there has been a revival of TOD, with emphasis on later twentieth-century and early twenty-first-century sustainability agendas, and a global growth in mass transit investment from rail-based systems such as light rail transit (LRT), metro systems and heavy rail, to bus-based modes such as bus rapid transit (BRT). High frequency of transit services is now essential as most people have the option of using cars (Knowles, 2016, 2017; Knowles et al., 2019 under review). New rapid transit systems increase personal mobility and physical accessibility to activity sites and provide better transport choices.

TOD may cover a spectrum of urban forms, for example, from lowmedium to high-density development (Dittmar and Ohland, 2003), but it is widely recognized as an efficient, durable and robust urban form creating relatively high-density, compact, mixed-use, and pedestrian and cyclistfriendly development (Curtis et al., 2009). In this way, TOD has potential to enhance sustainability - 'sustainable development that meets current needs without compromising the ability of future generations to meet their own needs' (Brundtland Report, 1987) - in a variety of interconnected and broadly socio-economic, political-economic, urban and environmental ways.

De-industrialization, loss of manufacturing jobs and urban decline affected many towns and cities in developed countries in the late twentieth century. TOD has been identified as a facilitator of urban economic growth, regeneration and urban renewal (Ferbrache and Knowles, 2016; Knowles, 2012; Knowles and Ferbrache, 2016) where, for example, TOD maximizes the land use potential around transit stations if it is supported at city level by land use zoning and planning powers (Kenworthy, 2006; Newman and Kenworthy, 2006). Proactive links between transport investment and land use planning have been shown to enhance urban, socio-economic and environmental sustainability. This contrasts with the dominant neoliberal, market-driven agenda in most developed countries since the 1980s that has degraded urban sustainability (Grengs, 2005). 
More broadly, TOD has helped to enhance urban sustainability agendas through city boosterism and place-making, helping to improve the reputation and aesthetic values of cities (Ferbrache and Knowles, 2017). It has also been linked to social goals including increased ridership levels, formation of civic and public spaces, and in itself is a hub for community development (Bernick and Cervero, 1997; Cervero, 2010). However, there is some evidence of TOD unintentionally increasing levels of economic segregation and leading to gentrification, as it usually increases land and property values which can displace poorer residents and lower-income economic activities (Rayle, 2015). Gentrification, 'the production of space for - and consumption by - a more affluent and very different incoming population' (Slater et al., 2004, p.1145), is not necessarily a negative process with negative outcomes. TOD is designed to attract middle- and higher-income households whose capital and socio-cultural investment in an area can further contribute to city centre revitalization. Some intended gentrification can also foster socio-economic, racial and ethnic integration towards a more equitable society (Freeman and Braconi, 2004; Zuk et al., 2018). These same processes of gentrification, however, can have negative impacts on different stakeholders where, for example, a rise in land and property prices can lead to displacement of lower-income households and exclusion of similar low-income individuals or families wishing to live in such areas (Rayle, 2015). This relationship between TOD, gentrification and displacement has often been framed as an obstacle in the ability of TOD to achieve various strands of sustainability, including sustainable mobility (Chava et al., 2018), social equity (Dong, 2017; Luckey et al., 2018), economic growth (Zuk et al., 2018) and environmental goals (Jones and Ley, 2016).

TOD is recognized as a key facilitator in achieving the revolution of transport without oil and in reducing car dependence (Gilbert and Perl, 2010; Newman and Kenworthy, 2015; Renne and Fields, 2013). In the twenty-first century, TOD has become a very important part of broader urban sustainability and 'smart growth' approaches to urban development and urban regeneration in many developed and emerging countries (Goetz, 2013; Hollands, 2008). Smart growth encourages higher-density urban development with lower economic, environmental and social costs than suburban sprawl. Smart cities aim to be efficient, technologically advanced, green and socially inclusive, and to underpin smart growth (Vanolo, 2014).

Transport investment, likewise, plays a role in sustainability agendas (Banister, 2008) and has been recognized as a key shaper of space (Knowles, 2006) and as a 'maker and breaker' of cities (Clark, 1958). Yet, it is widely understood that transport does not shape urban form 
independently; rather, it is part of a range of supportive policies, financial tools and infrastructure that includes integrated transport and planning initiatives (Bernick and Cervero, 1997; Cervero, 1998; Knight and Trygg, 1977). Land use policy controls the placement of activities and enables urban areas to shape expansion and development whilst reducing urban sprawl (Black, 2010). Some of the best examples of TOD in the urban transit literature emphasize the success of integrated transport and development planning: for instance, bus transit oriented development (BTOD) in Curitiba, Brazil (Lindau et al., 2010), and TOD integrated with Copenhagen's light rail mini-metro in Ørestad New Town (Knowles, 2012). Thus, it is widely recognized that to optimize TOD or the wider benefits of transport investment, urban planners and decision-makers need to develop integrated urban and transport planning. It is in this way too that TOD and public transport investment may best contribute to urban sustainability agendas.

Sustainable urbanism is just one example of an urban focus on development where 'sustainable' is used as a prefix. Sustainable mobility, transport and cities share similar goals as sustainable urbanism, to create ideal-type cities that boost high-quality environments in terms of economic prosperity, social equity goals, and a high quality of life and environment, without compromising these features for future populations who may use and inhabit the city. Examining the factors that comprise a sustainable city, Banister (2008, p. 73) identified some key parameters: 'over 25000 population (preferably over 50000), with medium densities (over 40 persons per hectare), with mixed use developments and with preference given to developments in public transport accessible corridors and near to highly public transport accessible interchanges'. Behind these characteristics lie goals for developing centres of urban life in which people can live, work and socialize in proximity, thus lessening the need to travel as far and as often (and particularly by private car). Reduction in car use and more emphasis on a walking, cycling and transit-oriented environment also serves to alleviate traffic congestion and carbon emissions. Investment in sustainable transport modes (that is, public transit, walking and cycling) and TOD remain significant foci within urban sustainability agendas, and many of the parameters of Banister's sustainable city are shared with those of TOD (Calthorpe, 2013; Cervero, 1998).

While we might argue that TOD provides a vision towards achieving sustainable cities, Cervero et al. (2004, p.119) advise caution, arguing that: 'The literature is replete with platitudes that have been heaped on the TOD concept'. The gap in the literature that they identify is one of few robust studies that draw out quantitative benefits of TOD. However, there is a wide range of existing work that documents and evaluates processes, 
experiences and outcomes of TOD in a more qualitative sense. This volume contributes to better understanding of TOD in specific contexts. Following this introduction, the rest of the book is structured into four parts.

\section{PART I: TOD, ECONOMIC DEVELOPMENT AND SUSTAINABILITY}

Six chapters examine aspects of TOD and economic development featuring research in the United States (US), Dubai, Malta, Italy and Canada. In Chapter 2, Schorung analyses urban regeneration in central area station districts in three diverse US high-speed rail corridors in San Francisco, Washington, DC and Miami. Although the first two are creating sustainable TOD, they all lack a broader planning perspective on incorporating sustainable development and encompassing the whole metropolitan area.

Hannawi, Jones and Titheridge examine recent and planned investment in rapid transit systems in the oil and gas-rich Gulf Cooperation Council countries in Chapter 3. They focus on retrofitting urban developments in Dubai City to the metro and light rail systems, and the changing attitudes of developers to TOD.

In Chapter 4, Attard explores the potential of LRT to encourage urban regeneration in Malta and support more sustainable commuting to and from its capital, Valletta. This small island country is one of the most car-dependent in Europe. A detailed assessment is undertaken of the TOD potential along the mixed-use Valletta-Ta' Qali route.

Bonvino, in Chapter 5, evaluates land value capture processes in TOD areas to fund capital investment in urban public transport. He examines the case of Metro Line 2 in Turin, Italy.

In Chapter 6, Barrieau explores modal choice and the role of TOD in Montréal, Canada. Montréal suffers from car-oriented low-density development and congestion, but lacks the tools for planning at the metropolitan level.

Goetz, in Chapter 7, examines the effects of the reintroduction of rail transit in Denver, Colorado on changing its urban development trajectory from low-density car-oriented decentralized growth to higher-density TOD in urban centres. 


\section{PART II: SOCIAL DEVELOPMENT AND SUSTAINABILITY}

In Chapter 8, Miner, Delmelle and Nilsson use $k$-means cluster analysis and Markov chains to analyse socio-economic neighbourhood change around heavy rail transit lines in three US cities: Atlanta, Miami and Washington, DC.

McAslan, in Chapter 9, explores how to build a more effective public transit system in Seattle by learning from resident transit use, behaviour and perspectives. Travel surveys and interviews draw on the theory of urban fabrics to explore Seattle's transportation crisis. New transit investment is uncoordinated and will not encourage TOD.

In Chapter 10, Keeling examines challenges and opportunities created by TOD strategies in two contrasting urban BRT corridors in Buenos Aires, one of South America's megacities.

\section{PART III: TOD METHODS}

Three chapters examine a range of methods for assessing TODs. In Chapter 11, Tanoz-Sargeant examines various methods of assessing TODs including multi-criteria analysis, computer-aided design (CAD)-based assessments, and pedestrian and traffic flows. Microsimulation models are then evaluated as a complementary and cost-effective tool to help assess and enhance TOD designs.

In Chapter 12, Papa uses stakeholder interviews to challenge approaches to TOD in London, and to highlight TOD opportunities by using policy measures adopted elsewhere.

Mabazza, in Chapter 13, examines the role of cheap, flexible and accessible informal public transport in major cities in developing countries. Survey data are used to examine the role of paratransit as a feeder mode to enhance mass transit in Manila, Philippines.

\section{PART IV: CONCLUSIONS}

Knowles and Ferbrache, in Chapter 14, make a critical synthesis of new knowledge on impacts of TOD and its potential to enhance urban sustainability. The chapter provides a comprehensive insight into TOD in economic, social and methodological ways that speaks to a more rounded understanding of sustainability. 


\section{REFERENCES}

Alonso, W. (1964), Location and Land Use. Cambridge, MA: Harvard University Press.

Banister, D. (2008), The sustainable mobility paradigm. Transport Policy, 15(2), 73-80.

Banister, D. (2011), The trilogy of distance, speed and time. Journal of Transport Geography, 19, 950-959.

Bernick, M., and Cervero, R. (1997), Transit Villages for the 21st Century. New York: McGraw-Hill.

Black, W.R. (2010), Sustainable Transportation: Problems and Solutions. New York, USA and London, UK: Guilford Press.

Brundtland Report (1987), Our Common Future. United Nations World Commission on Environment and Development. Oxford: Oxford University Press.

Calthorpe, P. (1993), The Next American Metropolis: Ecology, Community and the American Dream. Princeton, NJ: Princeton Architectural Press.

Calthorpe, P. (2013), Urbanism in the Age of Climate Change. Washington, DC: Island Press.

Cervero, R. (1998), The Transit Metropolis: A Global Inquiry. Washington, DC: Island Press.

Cervero, R. (2010), Transit transformations: private financing and sustainable urbanism in Hong Kong and Tokyo. In: Ascher, W., and Krupp, C. (eds), Physical Infrastructure Development: Balancing the Growth, Equity and Environmental Imperatives. New York: Palgrave Macmillan, 165-185.

Cervero, R., Arrington, G.B., Smith-Heimer, J.S., and Dunphy, R. (2004), Transitoriented development in the United States: experiences, challenges and prospects. Transit Cooperative Research Program, Report 102. Washington, DC.

Chava, J., Newman, P., and Tiwari, R. (2018), Gentrification of station areas and its impact on transit ridership. Case Studies on Transport Policy, 6(1), 1-10.

Christaller, W. (1966), Central Places in Southern Germany. Englewood Cliffs, NJ: Prentice Hall.

Clark, C. (1958), Transport - maker and breaker of cities. Town Planning Review, 28(4), 237-250.

Curtis, C., Renne, J.L., and Bertolini, L. (eds) (2009), Transit Oriented Development: Making It Happen. Farnham, UK and Burlington, VT, USA: Ashgate Publishing.

Dittmar, H., and Ohland, G. (2003), The New Transit Town: Best Practices in Transit-Oriented Development. Washington, DC: Island Press.

Dong, H. (2017), If you build rail transit in suburbs, will development come? Journal of the American Planning Association, 82(4), 316-326.

Ewing, R., and Cervero, R. (2010), Travel and the built environment: a metaanalysis. Journal of the American Planning Association, 76(3), 265-294.

Ferbrache, F., and Knowles, R.D. (2016), Generating opportunities for city sustainability through investments in light rail systems: introduction to the Special Section on Light Rail and Urban Sustainability. Journal of Transport Geography, 54, 369-372.

Ferbrache, F., and Knowles, R.D. (2017), City boosterism and place-making with light rail transit: a critical review of light rail impacts on city image and quality. Geoforum, 80, 103-113. 
Freeman, L., and Braconi, F. (2004), Gentrification and displacement. Journal of the American Planning Association, 70(1), 39-52.

Garreau, J. (1991), Edge City: Life on the New Frontier. New York: Doubleday.

Geurs, K.T., and van Wee, B. (2004), Accessibility evaluation of land-use and transport strategies: review and research directions. Journal of Transport Geography, 12(2), 127-140.

Gilbert, R., and Perl, A. (2010), Transport Revolutions: Moving People and Freight without Oil. London: Earthscan.

Goetz, A. (2013), Suburban sprawl or urban centres: tensions and contradictions of smart growth approaches in Denver, Colorado. Urban Studies, 50(11), $2178-2195$.

Grengs, J. (2005), The abandoned social goals of public transit in the neoliberal city of the USA. City, 9, 51-66.

Hansen, W.G. (1959), How accessibility shapes land use? Journal of the American Institute of Planners, 25, 73-76.

Hartshorn, T.A. (1992), Interpreting the City. New York: Wiley.

Hollands, R.G. (2008), Will the real smart city please stand up? City, 12(3), 303-320.

Hoyt, H. (1939), The Structure and Growth of Residential Neighbourhoods in American Cities. Washington, DC: Federal Housing Administration.

Jones, C.E., and Ley, D. (2016), Transit-oriented development and gentrification along Metro Vancouver's low-income SkyTrain corridor. Canadian Geographer, 60(1), 9-22.

Kenworthy, J.R. (2006), The eco-city: ten key transport and planning dimensions for sustainable city development. Environment and Urbanization, 18(1), 67-85.

Knight, R.L., and Trygg, L.L. (1977), Evidence of land use impacts of rapid transit systems. Transportation, 6, 231-247.

Knowles, R.D. (2006), Transport shaping space: differential collapse in time-space. Journal of Transport Geography, 13, 407-425.

Knowles, R.D. (2012), Transit oriented development in Copenhagen, Denmark: from the Finger Plan to Ørestad. Journal of Transport Geography, 22, 251-261.

Knowles, R.D. (2016), OURSUS: transport geographers: ideas and experiences about aspects of sustainable cities. International Geographical Congress, Beijing, China, 22 August.

Knowles, R.D. (2017), Urban rail investment and transit-oriented development: what are the links? Royal Geographical Society (with IBG) Conference, London, 1 September.

Knowles, R.D., and Ferbrache, F. (2016), Evaluation of the wider economic impacts of light rail investment on cities. Journal of Transport Geography, 543, 430-439.

Knowles, R.D., Ferbrache, F., and Nikitas, A. (2019 under review), Transport's historical, contemporary and future role in shaping urban development: reevaluating transit oriented development. Cities.

Lindau, L.A., Hildago, D., and Facchini, D. (2010), Curitiba, the cradle of bus rapid transit. Built Environment, 36(3), 274-282.

Luckey, K.S., Marshall, W.E., Durso, C., and Atkinson-Palombo, C. (2018), Residential preferences, transit accessibility and social equity: insights from the Denver region. Journal of Urbanism, 11(2), 149-174.

Newman, P., and Kenworthy, J. (2006), Urban design to reduce automobile dependence. Opolis: An International Journal of Suburban and Metropolitan Studies, 2(1), $35-52$. 
Newman, P., and Kenworthy, J. (2015), End of Automobile Dependence. Washington, DC: Island Press.

Rayle, L. (2015), Investigating the connection between transit-oriented development and displacement: four hypotheses. Housing Policy Debate, 25, 531-548.

Renne, J., and Fields, B. (eds) (2013), Transport Beyond Oil. Washington, DC: Island Press.

Slater, T., Curran, W., and Lees, L. (2004), Gentrification research: new directions and critical scholarship. Special Issue of Environment and Planning A, 36(7), $1141-1150$.

Vanolo, A. (2014), Smartmentality: the smart city as a disciplinary strategy. Urban Studies, 51, 883-898.

Zuk, M., Bierbaum, A.H., Chapple, K., Gorska, K., and Loukaitou-Sideris, A. (2018), Gentrification, displacement, and the role of public investment. Journal of Planning Literature, 33(1), 31-44. 